\title{
Template-Directed Dynamic Synthesis of Mechanically Interlocked Dendrimers
}

\author{
Ken C.-F. Leung, Fabio Arico, Stuart J. Cantrill, and J. Fraser Stoddart* \\ California NanoSystems Institute and Department of Chemistry and Biochemistry, The University of California, \\ Los Angeles, 405 Hilgard Avenue, Los Angeles, California 90095-1569
}

Received January 9, 2005; E-mail: stoddart@chem.ucla.edu

Recently, the versatility of dynamic covalent chemistry (DCC) ${ }^{1}$ has been demonstrated ${ }^{2}$ in the multicomponent construction of complex mechanically interlocked compounds, such as molecular bundles ${ }^{3}$ and nanoscale Borromean rings, ${ }^{4}$ as well as in the highly efficient template-directed synthesis ${ }^{5}$ of [2]rotaxanes. ${ }^{6}$ Previously, we have reported ${ }^{7}$ that, by employing DCC in the form of reversible imine bond formation, [2] rotaxanes with dialkylammonium ion $\left(-\mathrm{CH}_{2} \mathrm{NH}_{2}{ }^{+} \mathrm{CH}_{2}-\right)$ recognition sites ${ }^{8}$ encircled by [24]crown-8 macrocycles can be prepared in high yields by a thermodynamically controlled, templated self-assembly process, that is, a kind of clipping procedure (Figure 1), as a result of the mixing together of three different components, namely, a dialdehyde, a diamine, and a dumbbell compound containing a $-\mathrm{CH}_{2} \mathrm{NH}_{2}{ }^{+} \mathrm{CH}_{2}-$ center to template the [2] rotaxane formation. ${ }^{7}$ In the context of constructing mechanically interlocked dendrimers ${ }^{9,10}$ by employing a convergent templation procedure, we have explored ${ }^{11}$ the feasibility of using DCC to introduce dendrons onto multivalent cores carrying $-\mathrm{CH}_{2} \mathrm{NH}_{2}{ }^{+} \mathrm{CH}_{2}-$ centers on their sidearms to act as "hooks" round which "eyes" in the shape of diimine-containing [24]crown-8 macrocycles can be constructed in an activating environment. We report herein that dendritic dialdehydes $\mathbf{1 a}-\mathbf{c}$ from generation zero [G0] to generation two [G2], the diamine $\mathbf{2}$, and the trisammonium salt $3-\mathrm{H}_{3} \cdot 3 \mathrm{PF}_{6}$ can be self-assembled (Scheme 1) as three collections of seven components, each in one-pot, under equilibrium conditions to afford the imine-containing [G0]-[G2] mechanically interlocked dendrimers $4 \mathbf{a}-\mathbf{c}-\mathrm{H}_{3} \cdot 3 \mathrm{PF}_{6}$ in yields in excess of $90 \%$. These dynamic dendrimers can be converted into their kinetically stable, neutral amine-containing dendrimers $\mathbf{5 a}-\mathbf{c}$ by reduction (fixation) of the imine bonds using the $\mathrm{BH}_{3} \cdot \mathrm{THF}$ complex as the reducing agent, and then subsequently isolated as their fully protonated counterparts $\mathbf{5 a}-\mathbf{c}-\mathrm{H}_{3} \cdot 3 \mathrm{TFA}$ after acidification with trifluoroacetic acid (H-TFA).

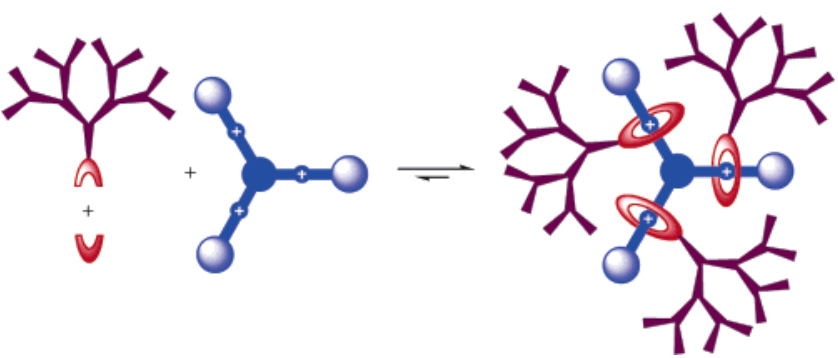

Figure 1. Graphical representation of the template-directed synthesis of mechanically interlocked dendrimers.

While the $[\mathrm{G} 0]-[\mathrm{G} 2]$ dendritic dialdehydes $\mathbf{1 a}-\mathbf{c}$ were obtained from their corresponding [G0]-[G2] dendritic bromides ${ }^{12}$ (see Supporting Information), the diamine $\mathbf{2}^{7}$ and the trisammonium salt $3-\mathrm{H}_{3} \cdot 3 \mathrm{PF}_{6}{ }^{1 \mathrm{~m}}$ were prepared according to procedures already described in the literature. The template-directed formation ${ }^{5}$ of the [G0]-[G2] dendrimers requires only the mixing of 3 molar equiv

5808 - J. AM. CHEM. SOC. 2005, 127, 5808-5810 of dendritic dialdehydes $\mathbf{1 a}-\mathbf{c}$ with 3 molar equiv of the diamine 2 and 1 molar equiv of the dialkylammonium salt $3-\mathrm{H}_{3} \cdot 3 \mathrm{PF}_{6}$ in either $\mathrm{CD}_{3} \mathrm{CN}$ or $\mathrm{CD}_{3} \mathrm{NO}_{2}$ (concentration $\sim 35 \mathrm{mM}$ ) at room temperature. Such clipping experiments were monitored directly by ${ }^{1} \mathrm{H}$ NMR spectroscopy. By way of an example, Figure 2 shows (upper trace) the ${ }^{1} \mathrm{H}$ NMR spectrum $\left(500 \mathrm{MHz}, \mathrm{CD}_{3} \mathrm{NO}_{2}, 298 \mathrm{~K}\right.$ ) of the dynamic [G2]-dendrimer $\mathbf{4} \mathbf{c}-\mathrm{H}_{3} \cdot 3 \mathrm{PF}_{6}$ recorded 5 min after mixing the three components in the requisite amounts $(3: 3: 1$ for 1:2:3- $\mathrm{H}_{3} \cdot 3 \mathrm{PF}_{6}$ ). The spectrum can be interpreted in terms of trace amounts of the starting materials plus the dynamic [G2]-dendrimer

Scheme 1. Seven-Component Self-Assemblies in One-Pot Procedures of the Dynamic Dendrimers $\mathbf{4 a}-\mathbf{c}-\mathrm{H}_{3} \cdot 3 \mathrm{PF}_{6}$
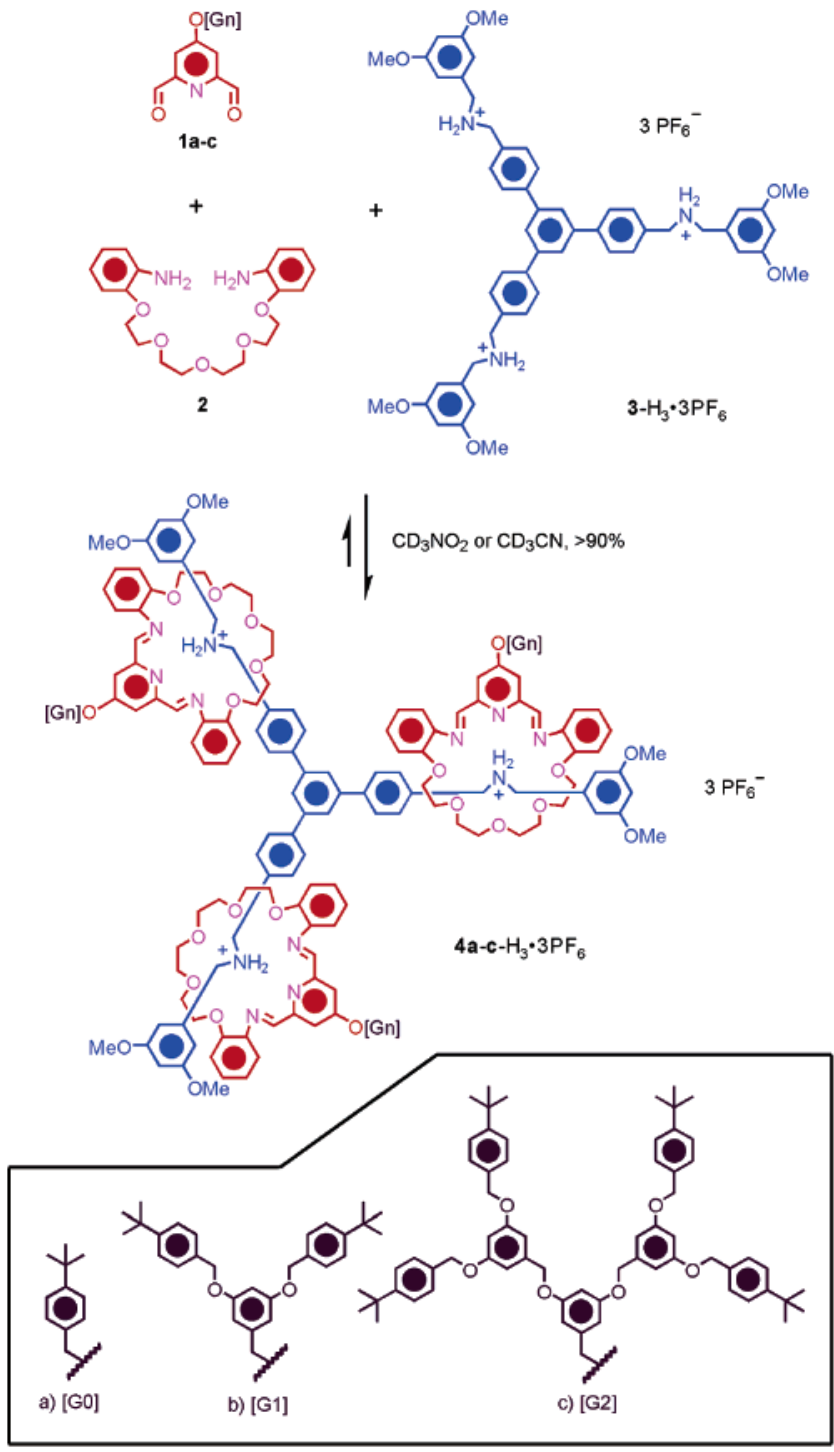

10.1021/ja0501363 CCC: $\$ 30.25$ @ 2005 American Chemical Society 


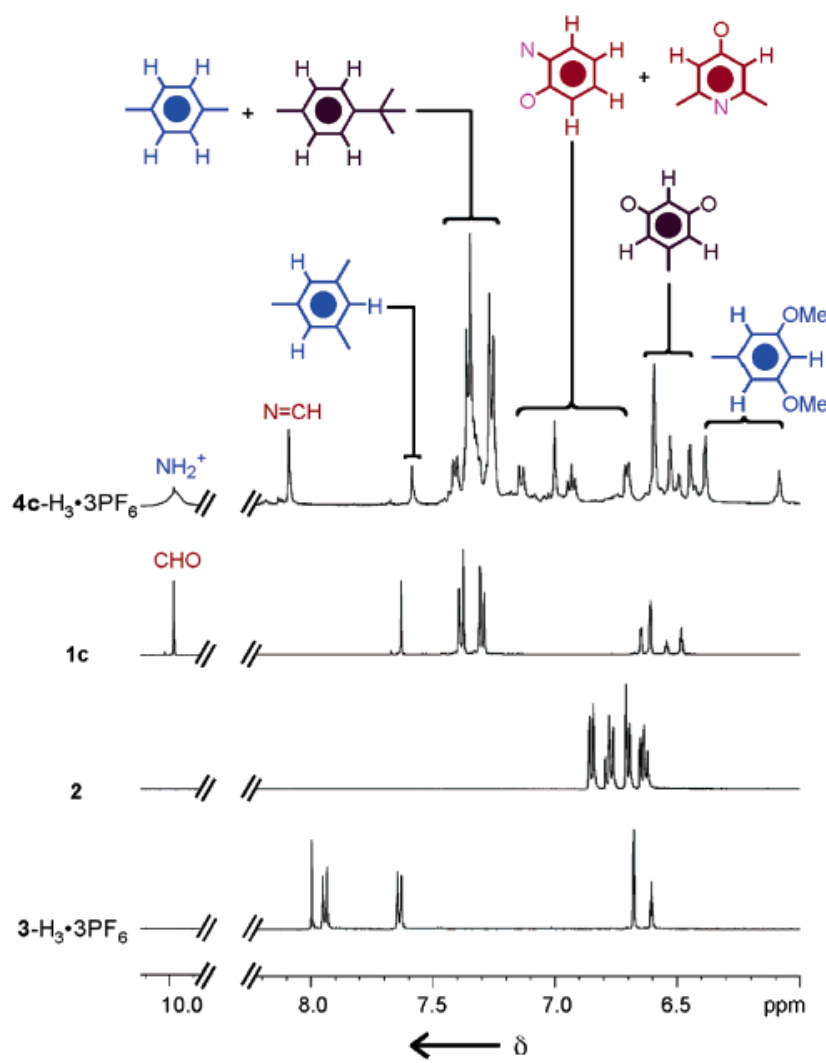

Figure 2. Partial ${ }^{1} \mathrm{H}$ NMR spectra $\left(500 \mathrm{MHz}, \mathrm{CD}_{3} \mathrm{NO}_{2}, 298 \mathrm{~K}\right)$ of the dynamic dendrimer $\mathbf{4 c}-\mathrm{H}_{3} \cdot 3 \mathrm{PF}_{6}$ in addition to the precursors $\mathbf{1 c}$, $\mathbf{2}$, and $3-\mathrm{H}_{3} \cdot 3 \mathrm{PF}_{6}$ from which it is self-assembled.

$\mathbf{4} \mathbf{c}-\mathrm{H}_{3} \cdot 3 \mathrm{PF}_{6}$ present in more than $90 \%$ yield. Specifically, the formation of $\mathbf{4} \mathbf{c}-\mathrm{H}_{3} \cdot 3 \mathrm{PF}_{6}$ is supported by the appearance of a sharp (singlet) resonance $(\delta=8.12 \mathrm{ppm})$ for the equivalent imine protons along with the disappearance of the singlet peak $(\delta=9.95 \mathrm{ppm})$ for the formyl protons in the [G2]-dialdehyde 1c. On the basis of their multiplicities and relative integrations, all of the other ${ }^{1} \mathrm{H}$ NMR signals in $\mathbf{4 c}-\mathrm{H}_{3} \cdot 3 \mathrm{PF}_{6}$ can be assigned to protons in the [G2]dendrimer. Similar characterizations were obtained for the [G0]and [G1]-dendrimers $\mathbf{4} \mathbf{a}-\mathrm{H}_{3} \cdot 3 \mathrm{PF}_{6}$ and $\mathbf{4} \mathbf{b}-\mathrm{H}_{3} \cdot 3 \mathrm{PF}_{6}$. In general, the ${ }^{1} \mathrm{H}$ NMR spectra of these dynamic dendrimers did not undergo any

Scheme 2. Fixing of the Kinetically Labile Dendrimers to Give the Neutral Dendrimers $5 \mathbf{a}-\mathbf{c}$ and Their Protonation to Yield $5 \mathbf{a}-\mathbf{c}-\mathrm{H}_{3} \cdot 3$ TFA.
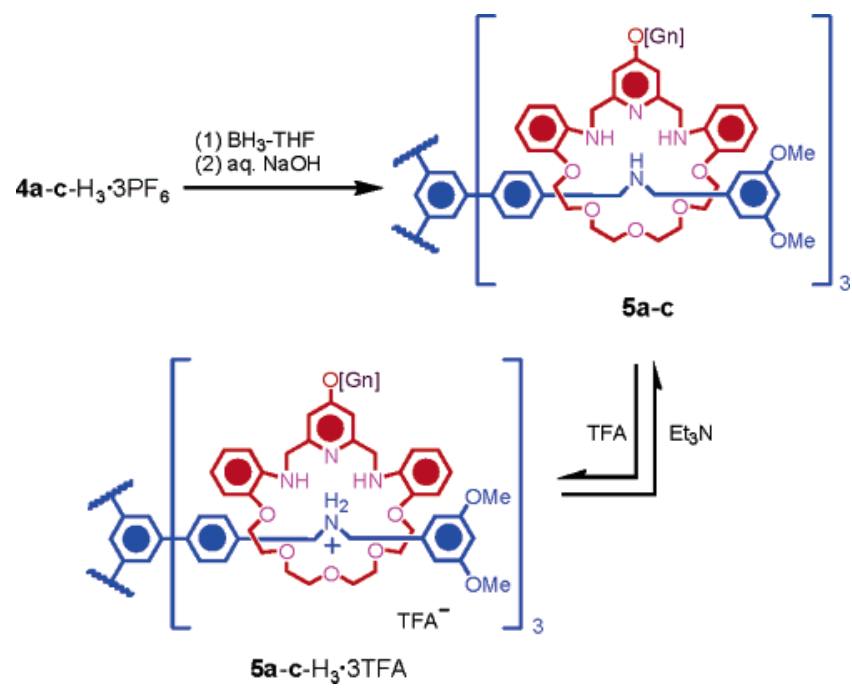

Table 1. ESI-MS Data for the Dynamic $\left(\mathbf{4 a}-\mathbf{c}-\mathrm{H}_{3} \cdot 3 \mathrm{PF} \mathrm{F}_{6}\right)$, the Neutral $(\mathbf{5 a}-\mathbf{c})$, and Protonated $\left(\mathbf{5 a}-\mathbf{c}-\mathrm{H}_{3} \cdot 3\right.$ TFA) Dendrimers

\begin{tabular}{llrr}
\hline \multicolumn{1}{c}{ structure } & molecular formula & \multicolumn{1}{c}{$\begin{array}{c}\text { calcd } \\
\mathrm{m} / \mathrm{z}\end{array}$} & \multicolumn{1}{c}{$\begin{array}{c}\text { found } \\
\mathrm{m} / \mathrm{z}\end{array}$} \\
\hline$\left[\mathbf{4 a}-\mathrm{H}_{3}\right]^{3+}$ & $\mathrm{C}_{168} \mathrm{H}_{189} \mathrm{~N}_{12} \mathrm{O}_{24}{ }^{3+}$ & 919.4646 & 919.4623 \\
{$\left[\mathbf{4 b}-\mathrm{H}_{3}\right]^{3+}$} & $\mathrm{C}_{222} \mathrm{H}_{249} \mathrm{~N}_{12} \mathrm{O}_{30}{ }^{3+}$ & 1187.6109 & 1187.6109 \\
{$\left[\mathbf{4} \mathbf{c}-\mathrm{H}_{3}\right]^{3+}$} & $\mathrm{C}_{330} \mathrm{H}_{369} \mathrm{~N}_{12} \mathrm{O}_{42}{ }^{3+}$ & 1723.9036 & 1723.9803 \\
$\mathbf{5 a}$ & $\mathrm{C}_{168} \mathrm{H}_{198} \mathrm{~N}_{12} \mathrm{O}_{24}$ & 2767.4637 & 2767.4680 \\
$\mathbf{5 b}$ & $\mathrm{C}_{222} \mathrm{H}_{258} \mathrm{~N}_{12} \mathrm{O}_{30}$ & 3571.9031 & 3572.0780 \\
$\mathbf{5 c}$ & $\mathrm{C}_{330} \mathrm{H}_{378} \mathrm{~N}_{12} \mathrm{O}_{42}$ & 5180.7812 & 5181.0500 \\
{$\left[\mathbf{5 a}-\mathrm{H}_{3}\right]^{3+}$} & $\mathrm{C}_{168} \mathrm{H}_{201} \mathrm{~N}_{12} \mathrm{O}_{24}{ }^{3+}$ & 923.4959 & 923.4968 \\
{$\left[\mathbf{5 b}-\mathrm{H}_{3}\right]^{3+}$} & $\mathrm{C}_{222} \mathrm{H}_{261} \mathrm{~N}_{12} \mathrm{O}_{30}{ }^{3+}$ & 1191.6422 & 1191.6762 \\
{$\left[\mathbf{5 c}-\mathrm{H}_{3}\right]^{3+}$} & $\mathrm{C}_{330} \mathrm{H}_{381} \mathrm{~N}_{12} \mathrm{O}_{42}{ }^{3+}$ & 1727.9349 & 1727.9941 \\
\hline
\end{tabular}

significant changes even after standing for more than $24 \mathrm{~h}$ at room temperature. This collective behavior demonstrates the remarkable stabilities of these mechanically interlocked dynamic compounds, presumably as much because of the numerous stabilizing $\left[\mathrm{N}^{+}-\right.$ $\mathrm{H} \cdots \mathrm{O}]$ hydrogen bonds and $[\mathrm{C}-\mathrm{H} \cdots \mathrm{O}]$ interactions as from the favorable charge transfer and other interactions involving $\pi$-donating and $\pi$-accepting aromatic rings.

On account of their six readily hydrolyzable imine bonds, the three kinetically labile [G0]-[G2]-dendrimers were fixed (Scheme 2 ) in each case by reduction $\left(\mathrm{BH}_{3} \cdot \mathrm{THF}\right)$, followed by deprotonation $\left(\mathrm{NaOH} / \mathrm{H}_{2} \mathrm{O}\right)$ to give the kinetically stable, neutral dendrimers $\mathbf{5 a}-$ c. In all cases, the reductions with the borane complex were a little less than quantitative. In general, however, mass spectrometry and ${ }^{1} \mathrm{H}$ NMR spectroscopy confirmed the presence of $\mathbf{5 a}-\mathbf{c}$ as the major products, which were also characterized as their fully protonated derivatives $\mathbf{5 a}-\mathbf{c}-\mathrm{H}_{3} \cdot 3 \mathrm{TFA}$. The average yield for the conversion of $\mathbf{4 a}-\mathbf{c}-\mathrm{H}_{3} \cdot 3 \mathrm{PF}_{6}$ through $\mathbf{5 a}-\mathbf{c}-\mathrm{H}_{3} \cdot 3 \mathrm{TFA}$ was around $80 \%$. For $\mathbf{5 a}-\mathbf{c}-\mathrm{H}_{3} \cdot 3 \mathrm{TFA}$, they can be deprotonated with triethylamine into their corresponding $\mathbf{5 a}-\mathbf{c}$ to switch off the numerous $\left[\mathrm{N}^{+}-\mathrm{H} \cdots \mathrm{O}\right]$ hydrogen bonds and $[\mathrm{C}-\mathrm{H} \cdots \mathrm{O}]$ interactions.

Electrospray ionization mass spectrometry (ESI-MS) proved to be a particularly useful technique for the mass analyses (Table 1) of $\mathbf{4} \mathbf{a}-\mathbf{c}-\mathrm{H}_{3} \cdot 3 \mathrm{PF}_{6}$ and $\mathbf{5} \mathbf{a}-\mathbf{c}-\mathrm{H}_{3} \cdot 3 \mathrm{TFA}$ and, hence, their characterization. ${ }^{13}$ By way of an example, the ESI-MS of the dynamic dendrimer $\mathbf{4 c}-\mathrm{H}_{3} \cdot 3 \mathrm{PF}_{6}$ revealed (Figure 3 ) a high-intensity signal at $m / z=1724.9738$ corresponding to the ion mass of $\left[4 \mathbf{c}-\mathrm{H}_{3}\right]^{3+}$, that is, the loss of $3 \mathrm{PF}_{6}$ ions from the salt.

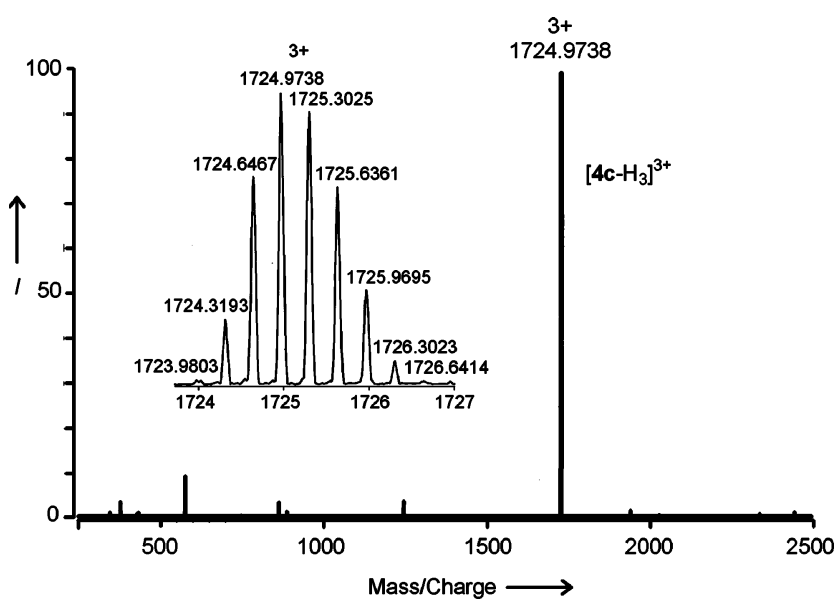

Figure 3. ESI-MS analysis of the dynamic dendrimer $4 \mathbf{c}-\mathrm{H}_{3} \cdot 3 \mathrm{PF}_{6}$.

We have found that, by taking advantage of dynamic covalent chemistry, ${ }^{1}$ dendrons from generation zero to two can be selfassembled in near quantitative yields into, first of all, kinetically labile and, then, kinetically stable mechanically interlocked dendrimers. These results demonstrate the potential for a modular 
approach to the convergent synthesis of dendrimers wherein the components can be mixed and matched according to the requirements of an even larger equilibrating system wherein the dynamic portion can, in principle, be altered and adapted to suit environments. A way of making mechanically interlocked dendrimers that is of practical value has been discovered.

Acknowledgment. The research was conducted as part of an NSF-NIRT award (ECS-0404458). We are grateful to the Croucher Foundation (HKSAR) for a postdoctoral fellowship to K.C.-F. L.

Supporting Information Available: Preparative procedures, spectroscopic data for all compounds reported in this communication, and complete ref 12. This material is available free of charge via the Internet at http://pubs.acs.org.

\section{References}

(1) (a) Brady, P. A. Sanders, J. K. M. Chem Soc Rev 1997, 26, 327-336. (b) Mohr, B.; Weck, M.; Sauvage, J.-P.; Grubbs, R. H. Angew. Chem. Int. Ed. Engl. 1997, 36, 1308-1310. (c) Hamilton, D. G.; Feeder, N.; Teat, S. J.; Sanders, J. K. M. New J. Chem. 1998, 1019-1021. (d) Weck, M.; Mohr, B.; Sauvage, J.-P.; Grubbs, R. H. J. Org. Chem. 1999, 64, 5463-5471. (e) Lehn, J.-M. Chem. Eur. J. 1999, 5, 2455-2463. (f) Cantrill, S. J.; Rowan, S. J.; Stoddart, J. F. Org. Lett. 1999, 1, 13631366. (g) Kidd, T. J.; Leigh, D. A.; Wilson, A. J. J. Am. Chem. Soc. 1999, 121, 1599-1600. (h) Belfrekh, N.; Dietrich-Buchecker, C. O.; Sauvage, J.-P. Inorg. Chem. 2000, 39, 5169-5172. (i) Rowan, S. J.; Cantrill, S. J.; Cousins, G. R. L.; Sanders, J. K. M.; Stoddart, J. F. Angew. Chem., Int. Ed. 2002, 41, 898-952. (j) Fuchs, B.; Nelson, A.; Star, A.; Stoddart, J. F. Angew. Chem., Int. Ed. 2003, 42, 4220-4224. (k) Aricó, F.; Mobian, P.; Kern, J.-M.; Sauvage, J.-P. Org. Lett. 2003, 5, 18871890. (1) Mobian, P.; Kern, J.-M.; Sauvage, J.-P. Angew. Chem., Int. Ed. 2004, 43, 2392-2395. (m) Badjic, J. D.; Cantrill, S. J.; Grubbs, R. H. Guidry, E. N.; Orenes, R.; Stoddart, J. F. Angew. Chem., Int. Ed. 2004 43, 3273-3278.

(2) Badjic, J. D.; Nelson, A.; Cantrill, S. J.; Turnbull, W. B.; Stoddart, J. F. Acc. Chem. Res. 2005, submitted.

(3) (a) Badjic, J. D.; Balzani, V.; Credi, A.; Lowe, J. N.; Silvi, S.; Stoddart, J. F. Chem. Eur. J. 2004, 10, 1926-1935. (b) Badjic, J. D.; Balzani, V.; Credi, A.; Stoddart, J. F. Science 2004, 303, 1845-1849.

(4) (a) Chichak, K. S.; Cantrill, S. J.; Pease, A. R.; Chiu, S.-H.; Cave, G. W V.; Atwood, J. L.; Stoddart, J. F. Science 2004, 304, 1308-1312. (b) Cantrill, S. J.; Chichak, K. S.; Peters, A. J.; Stoddart, J. F. Acc. Chem. Res. 2005, 38, 1-9.

(5) (a) Busch, D. H.; Stephenson, N. A. Coord. Chem. Rev. 1990, 100, 119154. (b) Philp, D.; Stoddart, J. F. Synlett 1991, 445-458. (c) Anderson, S.; Anderson, H. L.; Sanders, J. K. M. Acc. Chem. Res. 1993, 26, 469475. (d) Sneider, J. P.; Kelly, J. W. Chem. Rev. 1995, 95, 2169-2187. (e) Raymo, F. M.; Stoddart, J. F. Pure Appl. Chem. 1996, 68, 313-322. (f) Templated Organic Synthesis; Diederich, F., Stang, P. J., Eds.; WileyVCH: Weinheim, Germany, 1999. (g) Stoddart, J. F.; Tseng, H.-R. Proc. Natl. Acad. Sci. U.S.A. 2002, 99, 4797-4800.

(6) (a) Kilbinger, A. F. M.; Cantrill, S. J.; Waltman, A. W.; Day, M. W.; Grubbs, R. H. Angew. Chem., Int. Ed. 2003, 42, 3281-3285. (b) Hannam, J. S.; Kidd, J. T.; Leigh, D. A.; Wilson, A. J. Org. Lett. 2003, 5, 19071910. (c) Fuller, A.-M.; Leigh, D. A.; Lusby, P. J.; Oswald, I. D. H.; Parsons, S.; Walker, D. B. Angew. Chem., Int. Ed. 2004, 43, 3914-3918.

(7) (a) Glink, P. T.; Oliva, A. I.; Stoddart, J. F.; White, A. J. P.; Williams, D. J. Angew. Chem., Int. Ed. 2001, 40, 1870-1875. (b) Horn, M.; Ihringer, J.; Glink, P. T.; Stoddart, J. F. Chem. Eur. J. 2003, 9, 4046-4054.

(8) (a) Glink, P. T.; Schiavo, C.; Stoddart, J. F.; Williams, D. J. Chem. Commun. 1996, 1483-1490. (b) Hubin, T. J.; Kolchinski, A. G.; Vance, A. L.; Busch, D. H. Adv. Supramol. Chem. 1999, 5, 237-357. (c) Furusho, Y.; Oku, T.; Hasegawa, T.; Tsuboi, A.; Kihara, N.; Takata, T. Chem. Eur. J. 2003, 9, 2895-2903.

(9) For reviews and selected publications in dendrimer chemistry, see: (a) Fréchet, J. M. J.; Tomalia, D. A. Dendrimers and Other Dendritic Polymers; Wiley: New York, 2002. (b) Newkome, G. R.; Vögtle, F.;
Moorefield, C. N. Dendrimers and Dendrons: Concepts, Syntheses, Applications; VCH: New York, 2001. (c) Chow, H.-F.; Mong, T. K.-K.; Nongrum, M. F; Wan, C.-W. Tetrahedron 1998, 8543-8660. (d) Matthews, O. A.; Shipway, A. N.; Stoddart, J. F. Prog. Polym. Sci. 1998 23, 1-56. (e) Bosman, A. W.; Janssen, H. M.; Meijer, E. W. Chem. Rev. 1999, 99, 1665-1688. (f) Stoddart, F. J.; Welton, T. Polyhedron 1999 18, 3575-3591. (g) Vögtle, F.; Gestermann, S.; Hesse, R.; Schwierz, H.; Windisch, B. Prog. Polym. Sci. 2000, 25, 987-1041.

(10) For examples of dendritic pseudorotaxanes/rotaxanes, see: (a) Amabilino, D. B.; Ashton, P. R.; Balzani, V.; Brown, C. L.; Credi, A.; Fréchet, J. M. J.; Leon, J. W.; Raymo, F. M.; Spencer, N.; Stoddart, J. F.; Venturi, M. J. Am. Chem. Soc. 1996, 118, 12012-12020. (b) Yamaguchi, N.; Hamilton, L. M.; Gibson, H. W. Angew. Chem., Int. Ed. 1998, 37, 32753279. (c) Hübner, G. M.; Nachtsheim, G.; Li, Q. Y.; Seel, C.; Vögtle, F. Angew. Chem., Int. Ed. 2000, 39, 1269-1272. (d) Osswald, F.; Vogel, E.; Safarowsky, O.; Schwanke, F.; Vögtle, F. Adv. Synth. Catal. 2001, 343, 303-309. (e) Gibson, H. W.; Yamaguchi, N.; Hamilton, L. M.; Jones, J. W. J. Am. Chem. Soc. 2002, 124, 4653-4665. (f) Jones, J. W.; Bryant, W. S.; Bosman, A. W.; Janssen, R. A. J.; Meijer, E. W.; Gibson, H. W. J. Org. Chem. 2003, 68, 2385-2389.

(11) The history of this exploration in our laboratory has been frustrating, dominated as it has been, by both intricate and attractive procedures, but all lacking ultimately the efficiencies required to render them useful in a practical context. An approach which involves "threading-followed-bystoppering", and then, thereafter, "stopper exchange", has been used (Elizarov, A. M.; Chiu, S.-H.; Glink, P. T.; Stoddart, J. F. Org. Lett. 2002 4, 679-682) in a template-directed synthesis of a precursor bis[2]rotaxane that requires that a bisdibenzo[24]crown-8 core is threaded with a bis(bromomethyl)-substituted dibenzylammonium ion derivative before stoppering is achieved with an excess of $\mathrm{Ph}_{3} \mathrm{P}$. The best yield obtained in this sequence of reactions was $37 \%$ overall, a major byproduct being the intermediate mono[2] rotaxane isolated in $28 \%$ yield. Subsequent treatment of the bis[2]rotaxane with Fréchet-type wedge-shaped aldehydes (G1 and G2) effected Wittig reactions affording isomeric mixtures of tetraolefins, which were hydrogenated catalytically. The combined efficiencies of these final two steps were 70 and $75 \%$ for the G1 and G2 dendrimers, respectively. Thus, in a multistep synthesis that involves four separate steps, the first of which is the lowest yielding one, the best yield that has been obtained for dendrimers with rotaxane-like mechanical branching is below $30 \%$. In an attempt to find a more efficient route to mechanically interlocked dendrimers, we turned our attention (Elizarov, A. M.; Chang, T.; Chiu, S.-H.; Stoddart, J. F. Org. Lett. 2002, 4, 3565-3568) to the "slippage" approach in the knowledge (Ashton, P. R.; Baxter, I.; Fyfe, M. C. T.; Raymo, F. M.; Spencer, N.; Stoddart, J. F.; White, A. J. P. Williams, D. J. J. Am. Chem. Soc. 1998, 120, 2297-2307) that, in $\mathrm{CH}_{2} \mathrm{Cl}_{2}$ at $40{ }^{\circ} \mathrm{C}$, bis(cyclohexylmethyl)ammonium hexafluorophosphate $(50 \mathrm{mM})$ is converted $98 \%$ of the way to a [2]rotaxane in the presence of $150 \mathrm{mM}$ of dibenzo[24]crown-8 (DB24C8). In the event, this thermodynamically controlled self-assembly process lost all its remarkable efficiency on going from the model system to one that involves a Fréchet-type benzyl ether wedge and a DB24C8 unit which links another two such wedges. The best yield of a mechanically interlocked dendrimer that could be obtained in this single slippage experiment was $19 \%$, and this result involved a 90 day reaction period, followed by chromatography! This outcome was not exactly encouraging, and it took a considerable act of faith not to abandon a thermodynamically controlled approach to the synthesis of dendrimers containing mechanical bonds. It was against this background that we decided to explore the convergent template procedure, involving DCC in the context of imine bond formation. The fact that this one-step procedure goes in excess of $90 \%$ tells us that finally, at the third attempt, we have come up with a method that works that is sufficiently efficient to be of practical use in the synthesis of mechanically interlocked dendrimers.

(12) Stoddart, A. et al. Helv. Chim. Acta 2001, 84, 296-334.

(13) A competition experiment was performed by mixing 3 molar equiv each of $\mathbf{1 a}-\mathbf{c}, 3$ molar equiv of $\mathbf{2}$, and 1 molar equiv of $3-\mathrm{H}_{3} \cdot 3 \mathrm{PF}_{6}$ in $\mathrm{CD}_{3} \mathrm{NO}_{2}$ $(65 \mathrm{mM})$ to afford a mixture of nine dynamic dendrimers in one pot. ESI-MS revealed the absence of the $[\mathrm{G} 2] /[\mathrm{G} 2] /[\mathrm{G} 2]$ dynamic dendrimer in the mixture but the presence of all other eight dendrimers, with different combinations of dendron generations in almost equal amounts, with the exception of the $[\mathrm{G} 0] /[\mathrm{G} 0] /[\mathrm{G} 0]$ dynamic dendrimer, which was observed in only a trace amount.

JA0501363 